\title{
Production of agroindustrial ashes with pozzolanic activity via acid leaching, conjugated burning and ultrafine grinding
}

\author{
Produção de cinzas agroindustriais de elevada atividade \\ pozolânica via lixiviação, queima conjugada e moagem \\ ultrafina
}

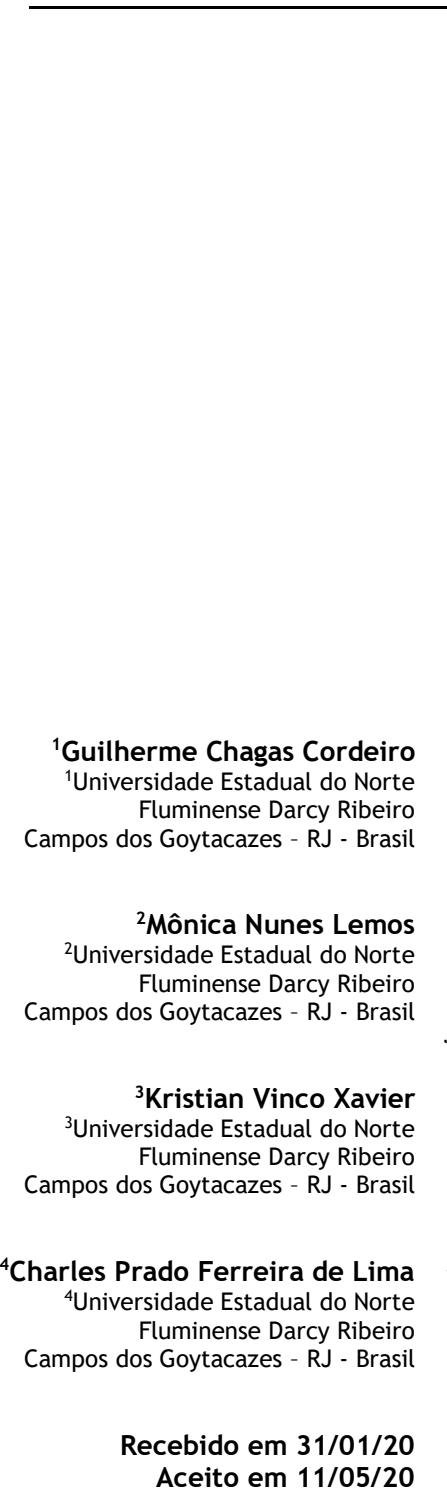

\section{Guilherme Chagas Cordeiro \\ Mônica Nunes Lemos \\ Kristian Vinco Xavier \\ Charles Prado Ferreira de Lima}

Abstract citric acid leaching, conjugated burning (thermal processing) and ultrafine grinding (mechanical processing) of the produced ashes. The results indicated that all ashes could be classified as pozzolanic additions based on specific standards. The high pozzolanicity of the ashes was confirmed by testing the electrical conductivity, mechanical performance index, and hydration kinetics of cement pastes by isothermal calorimetry. Therefore, the production processes used in this work were effective in producing highly reactive pozzolanic materials.

Keywords: Pozzolan. Agroindustrial ash. Ultrafine grinding. Conjugated burning. Acid leaching.

\section{Resumo}

Este trabalho objetiva estudar a produção e as características físicas e químicas de cinzas da casca de arroz, do bagaço da cana-de-açúcar, da folha de milho e da folha de bambu com vistas à aplicação como pozolanas. As etapas de produção das cinzas consistiram basicamente de coleta e preparação das matérias-primas, tratamento químico por lixiviação com ácido cítrico, queima conjugada (beneficiamento térmico) e moagem ultrafina das cinzas produzidas (beneficiamento mecânico). Os resultados indicaram que todas as cinzas atenderam aos requisitos de normas específica e foram classificadas como adições pozolânicas. A elevada pozolanicidade das cinzas foi confirmada em ensaios de condutividade elétrica, de índice de desempenho e pelas mudanças na cinética de hidratação de pastas cimentícias por calorimetria isotérmica. Portanto, os mecanismos de beneficiamento utilizados na produção das diferentes cinzas foram eficazes para geração de materiais pozolânicos altamente reativos.

Palavras-chave: Pozolana. Cinza agroindustrial. Moagem ultrafina. Queima conjugada. Lixiviação ácida. n. 4, p. 189-203, out./dez. 2020. 


\section{Introduction}

Civil construction is characterized by a set of processes that have significant environmental impacts due to high energy consumption and natural resources, in addition to greenhouse gas emissions and waste generation. One of the main environmental problems of civil construction is associated with the Portland cement production, which is the most used construction material around the world (GARTNER, 2004). Civil construction-related activities were responsible for around $2.6 \%$ of greenhouse gas intensifying emissions in Brazil in 2016 (AGÊNCIA FAPESP, 2016), especially $\mathrm{CO}_{2}$, which is released in large quantities during the production of Portland clinker.

Considering this, using industrial and agroindustrial wastes in partial replacement of Portland cement has been a viable alternative to mitigate the impacts of cement production, enabling the reuse of these waste materials (GANESAN; RAJAGOPAL; THANGAVEL, 2007). Pozzolanic and filler materials are used as mineral additions in commercially available cements worldwide. Pozzolans are defined as reactive aluminosilicates $\left(\mathrm{A}_{x} \mathrm{~S}_{y}\right)$, which can be amorphous (e.g. silica fume) or partially crystalline (e.g. metakaolin). Calcium silicate hydrate $(\mathrm{C}-\mathrm{S}-\mathrm{H})$ and calcium aluminate hydrate $(\mathrm{C}-\mathrm{A}-\mathrm{H})$ are the main products of the pozzolan reaction with portlandite $(\mathrm{CH})$ in the presence of water $(\mathrm{H})$, which are shown in Equation 1 . The precise composition of the $\mathrm{CSH}$ and $\mathrm{CAH}$ varies with the reaction conditions and the presence of other components (GARTNER, 2004). Calcium aluminosilicates (C-A-S-H) can also be formed in reactions involving pozzolans with significant amounts of amorphous alumina (RICHARDSON; GROVES, 1993).

$\mathrm{A}_{x} \mathrm{~S}_{y}+m \mathrm{CH}+n \mathrm{H} \rightarrow \mathrm{C}-\mathrm{S}-\mathrm{H}+\mathrm{C}-\mathrm{A}-\mathrm{H}$

Eq. 1

Studies on pozzolans have shown improvements in cementitious properties regarding rheological behavior (CORDEIRO; TOLEDO FILHO; FAIRBAIRN, 2008), durability (MALHOTRA; MEHTA, 1996; CORDEIRO; TOLEDO FILHO; FAIRBAIRN, 2008; HOPPE FILHO et al., 2014) and mechanical performance (MALHOTRA; MEHTA, 1996; CORDEIRO; TOLEDO FILHO; FAIRBAIRN, 2008; CORDEIRO et al., 2018). This is due to the increased formation of hydrates because of pozzolanic reactions (MALHOTRA; MEHTA, 1996; SOUZA et al., 2014) and the filler effect on cement pastes provided by the fine or ultrafine particles of mineral addition (LAWRENCE; CYR; RINGOT, 2003; CORDEIRO et al., 2008).

Pozzolans from waste generally need different processes to optimize their reactivity. In this respect, it is worth mentioning using thermal (SUGITA, 1994; SABIR; WILD; BAI, 2001; CORDEIRO; SALES, 2016; ROSSIGNOLO et al., 2018), mechanical (CORDEIRO; TAVARES; TOLEDO FILHO, 2016) and chemical (REAL; ALCALÁ; CRIADO, 1996; KRISHNARAO; SUBRAHMANUAM; JAGADISH KUMAR, 2001) processes used in the pozzolan production. Concerning chemical processes, Vayghan, Khaloo and Rajabipour (2013) showed that waste treatments with acid leaching can enhance the performance of ash in cementitious systems by increasing the concentration of amorphous silica due to the removal of metallic oxides, such as $\mathrm{Al}_{2} \mathrm{O}_{3}, \mathrm{Fe}_{2} \mathrm{O}_{3}, \mathrm{CaO}, \mathrm{MgO}, \mathrm{Na}_{2} \mathrm{O}$, and $\mathrm{K}_{2} \mathrm{O}$.

In this context, the present paper aims to study the production and main physical and chemical properties of ashes produced from sugarcane bagasse, rice husk, corn straw, and bamboo leaf to use as highly reactive pozzolans. Choosing these wastes is justified by the wide supply of bagasse, rice husk, and corn and bamboo leaves in Brazil, estimated at around 20 million tons in 2019 (INSTITUTO..., 2020; JUDZIEWICZ et al., 1999), and by the predominant presence of silica in its chemical compositions (ZHANG; MALHOTRA, 1996; MARTIRENA HERNÁNDEZ et al., 1998; CORDEIRO et al., 2008; ADESANYA; RAHEEM, 2009; VILLAR-COCIÑA et al., 2011).

\section{Materials and methods}

Rice husk ash (RHA) was used as a control pozzolan since this material has high pozzolanic activity (MALHOTRA; MEHTA, 1996; TASHIMA et al., 2012), especially when it is produced from burning acidleached husk (REAL; ALCALÁ; CRIADO, 1996; KRISHNARAO; SUBRAHMANYAM; JAGADISH KUMAR, 2001). RHA was produced from a rice husk sample collected in the city of Mogi das Cruzes-SP (Brazil). Samples of bagasse and bamboo leaf were collected in the city of Campos dos Goytacazes-RJ (Brazil) and used for producing sugarcane bagasse (SBA) and bamboo leaf (BLA) ashes, respectively. The corn straw sample used to produce ash (denominated CSA) was obtained from the city of Castelo-ES (Brazil).

190 Cordeiro, G. C.; Lemos, M. N.; Xavier, K. V.; Lima, C. P. F. de 
Figure 1 shows a flowchart with the sequence of activities used to produce the three ashes. After collection, all raw materials were washed in water to eliminate any impurities from the collection environment, followed by oven-drying at $100{ }^{\circ} \mathrm{C}$ for $24 \mathrm{~h}$. To produce RHA, CSA, and BLA, the raw materials were subjected to chemical treatment via leaching with a $10 \%$ anhydrous citric acid solution $\left(\mathrm{C}_{6} \mathrm{H}_{8} \mathrm{O}_{7}\right)$. The leaching of the materials was carried out for $72 \mathrm{~h}$ at room temperature at a proportion of $60 \mathrm{~g}$ of raw material to $1 \mathrm{~L}$ of acid solution. Afterwards, each sample was rinsed continuously with deionized water and then filtered with qualitative filter paper until $\mathrm{pH}$ neutralization. Finally, the leached material was oven-dried at $100{ }^{\circ} \mathrm{C}$ for $24 \mathrm{~h}$. These conditions were adapted from Cordeiro, Vieira and Lopes (2017) after changing the type of acid ( $\mathrm{HCl}$ in the previous study).

After leaching, the rice husk, corn straw, and bamboo leaf were subjected to conjugate burning, which consisted of burning in two stages according to the procedures suggested by Andreão et al. (2019). In the conjugate burning, the leached materials were initially burned in a pilot kiln adapted from Sugita (1994) using the biomass as fuel to reduce the amount of organic matter (volume reduction) and energy savings. This preliminary autogenous burning was not controlled, although the temperature was continuously monitored with thermocouples to ensure that it did not exceed $800{ }^{\circ} \mathrm{C}$, a temperature beyond which silica crystallization may occur (DELLA; KÜHN; HOTZA, 2002). Figure 2 shows the typical temperature evolution over $10 \mathrm{~h}$ of burning in the pilot kiln. In this case, it can be observed that the maximum temperature observed was $646{ }^{\circ} \mathrm{C}$ and the maximum heating rate was approximately $18{ }^{\circ} \mathrm{C} / \mathrm{min}$, which occurred in the first hour of burning. Subsequently, the three ashes generated in the first stage were reburned in a muffle furnace at $600{ }^{\circ} \mathrm{C}$ under oxidizing environment, with a heating rate of $10{ }^{\circ} \mathrm{C} / \mathrm{min}$ and residence time of $15 \mathrm{~min}$, as shown in Figure 2. Figure 3 shows the CSA appearance after burning in the pilot (Figure 3a) and muffle kilns (Figure 3b).

The production of SBA was carried out using the same processes previously presented, except for the leaching step with citric acid, which was carried out between the two burning stages (Figure 1). This change occurred due to the reduced SBA yield compared to the other studied ashes. In addition, it was interesting to simulate in the laboratory the production of an ash simulating that from the particulate collector in sugar and alcohol plants (CORDEIRO; ANDREÃO; TAVARES, 2019). This behavior was verified by burning the bagasse in pilot kiln that presented an average yield of $2.3 \%$ by mass. Yields of RHA, CSA, and BLA in the first burning were 22,13 , and $23 \%$, respectively.

Figure 1 - Flowchart of production processes of ashes

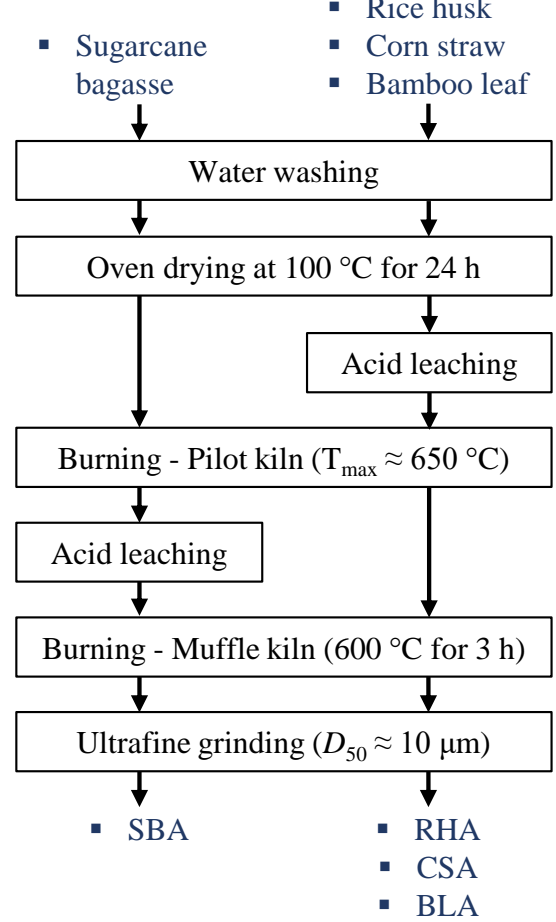


Figure 2 -Temperature evolution over time for two burning processes

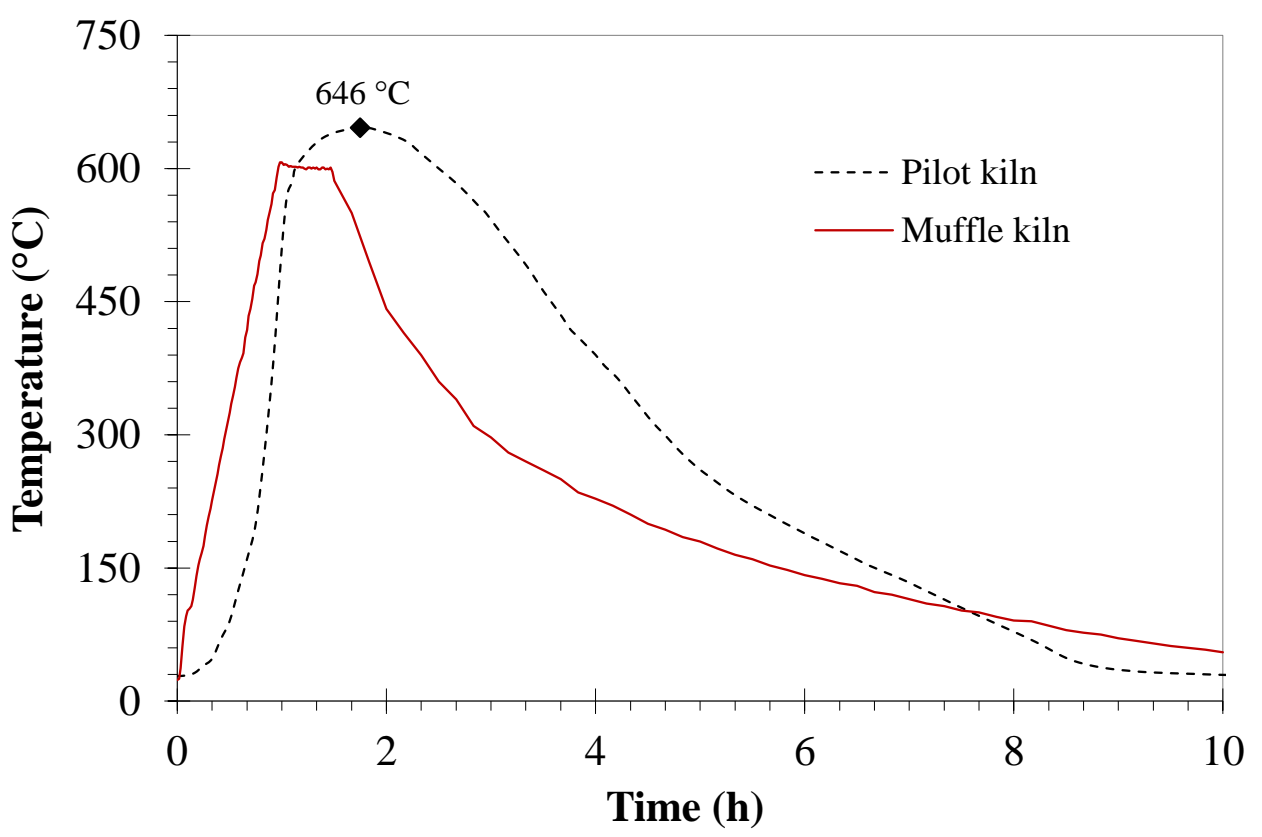

Figure 3 - Interior of the pilot kiln with corn straw ash (a) and appearance of the ash after burning in the muffle kiln (b)

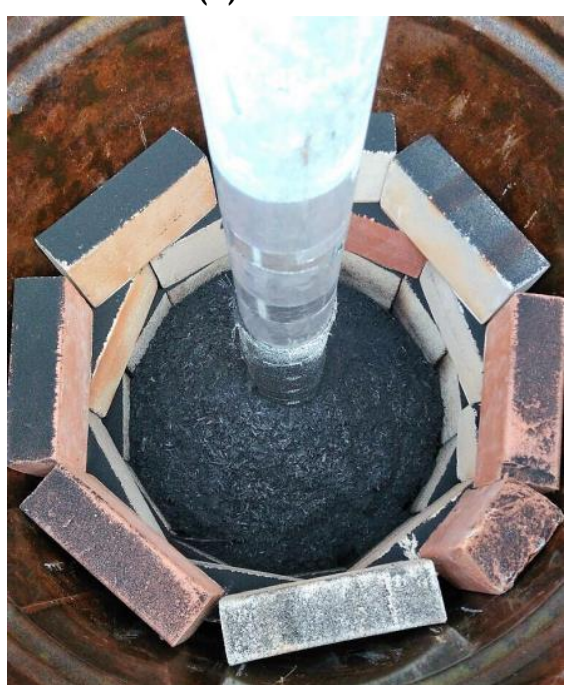

(a)

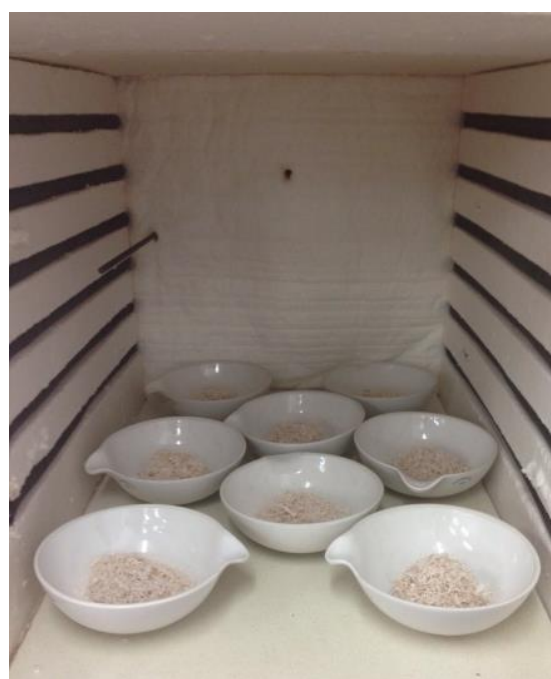

(b)

After burning, the four ashes were ground in a high-energy attrition mill (Union Process) in order to obtain products with similar granulometries and $D_{50}$ around $10 \mu \mathrm{m}$ (CORDEIRO; ANDREÃO; TAVARES, 2019). The grinding conditions were adapted from Andreão et al. (2019), as follows:

(a) operating speed of $500 \mathrm{rpm}$;

(b) feed mass of $100 \mathrm{~g}$;

(c) $3.5 \mathrm{~kg}$ of spherical grinding bodies ( $2 \mathrm{~mm}$ diameter) of zirconia; and

(d) grinding time of $30 \mathrm{~min}$.

The oxide composition was obtained by semi-quantitative analysis using an X-ray fluorescence spectrometer (Shimadzu EDX-720). Loss on ignition was obtained in accordance with NBR NM 18 (ABNT, 2012). The particle size distribution was determined by laser diffraction testing (Malvern Mastersizer 2000), with 15 min of dispersion in deionized water. The pore structure and BET specific surface area of the ashes were 
obtained in a nitrogen adsorption analyser (Micromeritics Tristar II 3020), with a sample treatment at $120{ }^{\circ} \mathrm{C}$ under vacuum for $12 \mathrm{~h}$. The mineralogical composition was investigated by X-ray diffraction using a Rigaku Miniflex 600 equipment, operating with $\mathrm{Cu}-\mathrm{K} \alpha_{1}$ radiation $(\lambda=0.15406 \mathrm{~nm}), 40 \mathrm{kV}$ voltage, $15 \mathrm{~mA}$ current, $0.02^{\circ}$ step, and $5^{\circ} / \mathrm{min}$ angular speed. Data were collected in a $2 \theta$ angular interval between 8 and $50^{\circ}$. The quantification of the crystalline phases was performed by Rietveld refinement (LIU; KUO, 1996) using PDXL v. 2 software. The crystallographic information was obtained from Jorgensen (1978). Amorphous content was determined using anatase as the internal standard.

The pozzolanic activity of the ashes was evaluated by electrical conductivity of samples in alkaline solution according to the method proposed by Luxán, Madruga and Saavedra (1989). For this, a suspension was prepared with $98.7 \mathrm{mg}$ of calcium hydroxide, $70 \mathrm{~g}$ of deionized water, and $1.75 \mathrm{~g}$ of sample. The conductivity variation was monitored for $20 \mathrm{~min}$ at $40 \pm 1{ }^{\circ} \mathrm{C}$ using the Alfakit AT 230 conductivity meter. It should be noted that previous results of electrical conductivity variation obtained for sugarcane straw ashes showed an excellent correlation from the results of the modified Chapelle (CORDEIRO; VIEIRA; LOPES, 2017).

Pozzolanic activity was also investigated by the mechanical performance index based on NBR 5752 (ABNT, 2014). The performance index is obtained from the relationship between the compressive strength at 28 days of a mortar with a $25 \%$ cement replacement by the mineral addition and the strength of a reference mortar. The mortar mix-design was established for water-binder (cement and ash) and sand-binder ratios of 0.48 and 3.0, respectively. A class $\mathrm{G}$ cement (ABNT, 2006) was used in this test. The chemical composition, density, and Blaine fineness of cement are presented in Table 1. Table 2 displays the contents of superplasticizer (ether carboxylic-based with $28.9 \%$ oven-dried residue and $1.12 \mathrm{~g} / \mathrm{cm}^{3}$ density) used in each mix to keep the same consistency for all mortars. For each mix, 4 cubic specimens of 50-mm edge were moulded and were kept in the molds for $24 \mathrm{~h}$ in a humid environment. After this period, the specimens were demoulded and kept immersed in a lime-saturated solution for 28 days. The axial compression tests were performed using a Shimadzu UHI-500kN testing machine, with a loading rate of $0.5 \mathrm{~mm} / \mathrm{min}$.

The hydration kinetics in cementitious pastes was evaluated using isothermal conduction calorimetry tests. In this case, pastes were made with 10 and 20\% (in mass) cement replacement by each type of ash, besides a reference paste (without ash). Class G cement (Table 1), deionized water, and ether carboxylic-based superplasticizer were used. The paste mix-design was defined based on a water-binder ratio of 0.4 . Table 3 shows the content of superplasticizer used in making the same consistency pastes. The pastes were named PREF (reference) and P- $X-Y$, where $X$ was the type of ash and $Y$ the cement replacement used (\% by mass).

Table 1 - Oxide composition, loss on ignition, density, and Blaine fineness of cement

\begin{tabular}{l|l}
\hline Oxide & \% in mass \\
\hline $\mathrm{SiO}_{2}$ & 16.15 \\
$\mathrm{~K}_{2} \mathrm{O}$ & 0.85 \\
$\mathrm{Al}_{2} \mathrm{O}_{3}$ & 3.23 \\
$\mathrm{CaO}$ & 69.10 \\
$\mathrm{SO}_{3}$ & 3.60 \\
$\mathrm{P}_{2} \mathrm{O}_{5}$ & - \\
$\mathrm{Fe}_{2} \mathrm{O}_{3}$ & 5.66 \\
$\mathrm{Na}_{2} \mathrm{O}$ & 0.22 \\
$\mathrm{MnO}$ & 0.10 \\
$\mathrm{TiO}_{2}$ & - \\
$\mathrm{Na}_{2} \mathrm{O}_{\text {eq }}$ & 0.78 \\
Loss on ignition & 1.09 \\
\hline Density & $3.17 \mathrm{~g} / \mathrm{cm}^{3}$ \\
Blaine fineness & $290 \mathrm{~m} / \mathrm{kg}$ \\
\hline
\end{tabular}

Note: ${ }^{*} \mathrm{Na}_{2} \mathrm{O}_{\mathrm{eq}}=\mathrm{Na}_{2} \mathrm{O}+0.658 \times \mathrm{K}_{2} \mathrm{O}$. 
Table 2 - Superplasticizer (SP) content of mortars

\begin{tabular}{c|c|c|c|c|c}
\hline Mortar & M-REF** & M-RHA & M-SBA & M-CSA & M-BLA \\
\hline SP $(\%)^{*}$ & 0.065 & 0.844 & 0.504 & 0.546 & 0.546 \\
\hline
\end{tabular}

Note: *\% solids in relation to binder mass; and

${ }^{* *} M-R E F$ - reference mortar; $M-X$ mortar containing the ash $X$ (RHA, SBA, CSA, and BLA).

Table 3 - Superplasticizer content of pastes

\begin{tabular}{c|c|c|c|c|c|c|c|c|c}
\hline \multirow{2}{*}{ Paste } & P- & P-RHA- & P-RHA- & P-SBA- & P-SBA- & P-CSA- & P-CSA- & P-BLA- & P-BLA \\
& REF & $\mathbf{1 0}$ & $\mathbf{2 0}$ & $\mathbf{1 0}$ & $\mathbf{2 0}$ & $\mathbf{1 0}$ & $\mathbf{2 0}$ & $\mathbf{1 0}$ & $\mathbf{2 0}$ \\
\hline SP $(\%) *$ & 0.03 & 0.10 & 0.21 & 0.05 & 0.10 & 0.07 & 0.13 & 0.07 & 0.13 \\
\hline
\end{tabular}

Note: *\% solids in relation to binder mass.

All pastes were mixed following the same procedure, which consisted of homogenization of deionized water and superplasticizer, followed by manual mixing of the liquid part and binder material with a spatula for 30 s. Next, the mixing was concluded in a portable electric mixer for $30 \mathrm{~s}$ at $260 \mathrm{rpm}$, followed by $60 \mathrm{~s}$ at 600 rpm. Immediately after the mixing end, samples of each mix were inserted into the Calmetrix I-CAL 2000 isothermal calorimeter. The pastes were monitored for the heat release profile for $72 \mathrm{~h}$ at $25 \pm 0.1{ }^{\circ} \mathrm{C}$.

\section{Results and discussion}

Table 4 shows the oxide composition and loss on ignition of different ashes, which showed a predominant presence of silica $\left(\mathrm{SiO}_{2}\right)$ in their compositions (around 90\%). On the other hand, there were low levels of contaminating oxides in the four ashes, such as $\mathrm{K}_{2} \mathrm{O}, \mathrm{CaO}$ and $\mathrm{SO}_{3}$. These compounds are highly undesirable in cement mixes, mainly because they cause durability problems, such as alkali-aggregate reactions (MEHTA; MONTEIRO, 2014). The $\mathrm{SO}_{3}$ content was lower in the four ashes than those observed for cement (Table 1) and the limit of 4\% established for pozzolans in NBR 12653 (ABNT, 2015). The same can be observed in relation to NBR 16697 (ABNT, 2018), which limits the $\mathrm{SO}_{3}$ content for commercial cements in Brazil to $4.5 \%$. The high concentration of silica in the ashes and the low levels of contaminating oxides highlighted the influence of acid leaching in the purification process of the studied materials. Similar results were previously observed (KRISHNARAO; SUBRAHMANYAM; JAGADISH KUMAR, 2001; VAYGHAN; KHALOO; RAJABIPOUR, 2013; CORDEIRO; SALES, 2016; CORDEIRO; VIEIRA; LOPES, 2017). The values of loss on ignition values, also presented in Table 4, showed low levels of carbonaceous material in the ashes after two-stage burning. All values were significantly lower than the maximum content of 5\% established by NBR 12653 (ABNT, 2015). The presence of residual carbonaceous material in the ashes reduced the concentration of silica and also promoted a delay in cement hydration reactions (CORDEIRO; BARROSO; TOLEDO FILHO, 2018).

Particle size distribution curves shown in Figure 4 revealed similar granulometries for RHA, SBA, CSA, and BLA. These results showed the efficiency of the grinding process in giving similar sizes to the four ashes, which was the necessary condition for an accurate evaluation of the pozzolanic effect of the ashes since the pozzolanic activity is strongly influenced by the particle size (CORDEIRO et al., 2011; CORDEIRO; KURTIS, 2017). The small differences among the ash granulometry for the same grinding condition indicated different grindability, which is characteristic for agroindustrial silica-based ashes (RIBAS et al., 2014; CORDEIRO; TAVARES; TOLEDO FILHO, 2016). All ashes presented $D_{50}$ values close to $10 \mu \mathrm{m}$ and lower than the characteristic value of the cement used $(14.9 \mu \mathrm{m})$. It should be noted that the $D_{50}$ of the four ashes were similar to those studied by Andreão et al. (2019) for sugarcane bagasse samples with strong contamination by quartz produced in an attritor mill.

Gas adsorption isotherms of the ashes are shown in Figure 5. It can be observed that the adsorption and desorption isotherms presented a similar trend for the four ashes, which is characteristic of meso and macroporous materials according to the IUPAC classification (THOMMES et al., 2015). This behavior is typical of a highly porous sample, as are the agroindustrial ashes for example, whose pore network has been significantly affected by high-energy grinding (VIEIRA et al., 2020). The results of the BET specific surface area, shown in Table 5, confirmed the presence of porous particles in the ashes, mainly RHA, CSA, and BLA. SBA was slightly penalized by the difference in its production process, which was necessary to adapt the characteristics of this ash to those observed for ashes originated from particulate collectors in sugar and alcohol plants. It is worth noting that the high values BET specific surface area observed for RHA, CSA, and

194 Cordeiro, G. C.; Lemos, M. N.; Xavier, K. V.; Lima, C. P. F. de 
BLA were due to acid leaching of raw materials before burning and grinding procedures. The specific surface area values are in accordance with those observed for agroindustrial ashes reported by Della, Kühn and Hotza (2002), Cordeiro, Vieira and Lopes (2017) and Vieira et al. (2020).

Table 4 - Oxide composition and loss on ignition of ashes (\% in mass)

\begin{tabular}{c|c|c|c|c}
\hline Oxide & RHA & SBA & CSA & BLA \\
\hline $\mathrm{SiO}_{2}$ & 92.25 & 90.80 & 89.11 & 91.00 \\
$\mathrm{~K}_{2} \mathrm{O}$ & - & 2.32 & 2.10 & - \\
$\mathrm{Al}_{2} \mathrm{O}_{3}$ & 2.92 & - & - & - \\
$\mathrm{CaO}$ & 0.10 & 0.90 & 1.60 & 3.95 \\
$\mathrm{SO}_{3}$ & 1.33 & 2.28 & 2.69 & 2.55 \\
$\mathrm{P}_{2} \mathrm{O}_{5}$ & - & - & 0.90 & - \\
$\mathrm{Fe}_{2} \mathrm{O}_{3}$ & 0.29 & 1.60 & 0.30 & 0.31 \\
$\mathrm{Na}_{2} \mathrm{O}$ & 0.10 & - & - & 0.10 \\
$\mathrm{MnO}$ & - & 0.10 & - & - \\
$\mathrm{TiO}_{2}$ & - & - & 0.10 & 0.10 \\
Loss on ignition & 3.01 & 2.00 & 3.20 & 2.00 \\
\hline
\end{tabular}

Figure 4 - Particle size distribution of cement and agroindustrial ashes

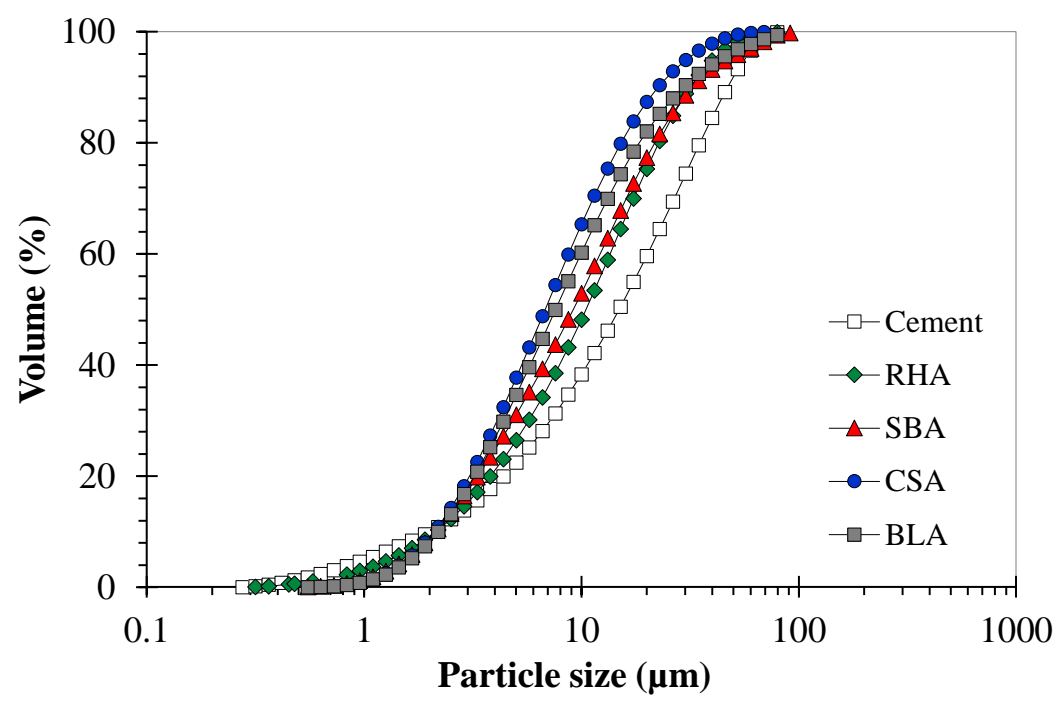

Figure 5 - Nitrogen adsorbed gas isotherms for all ashes

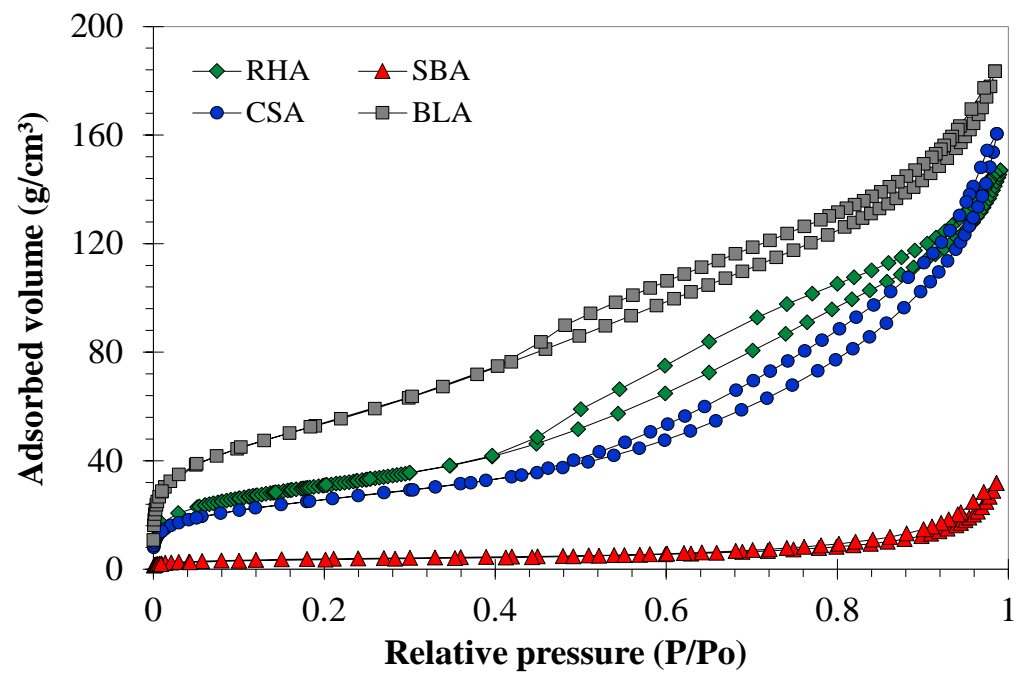


Table 5 - Main physical properties of ashes

\begin{tabular}{c|c|c|c|c}
\hline Ash & $\boldsymbol{D}_{\mathbf{5 0}}(\boldsymbol{\mu m})$ & $\begin{array}{c}\text { BET specific } \\
\text { surface area }\left(\mathbf{m}^{\mathbf{2}} \mathbf{/ k g}\right)\end{array}$ & $\begin{array}{c}\boldsymbol{\Delta} \mathbf{C}^{*} \\
(\mathbf{m S} / \mathbf{c m})\end{array}$ & $\begin{array}{c}\text { PI** } \\
(\boldsymbol{\%})\end{array}$ \\
\hline RHA & 10.5 & 63,232 & 5.78 & 136 \\
SBA & 9.2 & 13,332 & 0.74 & 107 \\
CSA & 6.8 & 91,630 & 3.73 & 148 \\
BLA & 7.6 & 199,000 & 5.91 & 140 \\
\hline
\end{tabular}

Note: * $\Delta C$ - variation of electrical conductivity (LUXÁN; MADRUGA; SAAVEDRA, 1989); and **PI - pozzolanic performance index (ABNT, 2014).

X-ray diffractograms of the ashes are shown in Figure 6. A typical silica amorphous halo can be seen between $2 \theta$ angles of 15 and $30^{\circ}$, indicating that the burning and grinding procedures were adequate to maintain the silica originally present in the plants in an amorphous state. This characteristic is fundamental for pozzolanic production and was previously observed for rice husk (REAL; ALCALÁ; CRIADO, 1996; KRISHNARAO; SUBRAHMANYAM; JAGADISH KUMAR, 2001; DELLA; HÜHN; HOTZA, 2002), sugar cane straw (CORDEIRO; VIEIRA; LOPES, 2017), and elephant grass (CORDEIRO; SALES, 2016) ashes. In fact, the four ashes were predominantly amorphous and did not contain crystalline phases with significant content. Based on Rietveld's refinement, SBA was the only ash to present quantifiable phases with quartz and hematite contents of $1.8 \%( \pm 0.5 \%)$ and $0.2 \%( \pm 0.1 \%)$, respectively.

Results of electrical conductivity tests for all ashes in calcium hydroxide solution are shown in Figure 7. Initially, there was a considerable drop in conductivity for the RHA, CSA, and BLA samples. The conductivity variation increased during the tests, which was an indication of the continuity of reactions between ashes and calcium hydroxide, especially the CSA. At 2 min of testing, the electrical conductivity variation values for RHA, CSA, and BLA were $5.78,3.73$, and $5.91 \mathrm{mS} / \mathrm{cm}$, respectively, as shown in Table 5. According to the classification proposed by Luxán, Madruga and Saavedra (1989), the 2-min variations indicated that the three ashes showed good pozzolanicity since $\Delta \mathrm{C}$ values after 2 min of test were significantly greater than $1.2 \mathrm{mS} / \mathrm{cm}$. Similar electrical conductivity results have been reported by and in studies with rice husk (FENG et al., 2004) and cane straw (CORDEIRO; VIEIRA; LOPES, 2017) ashes, which were both generated after treating of raw materials with hydrochloric acid leaching. SBA had $\Delta \mathrm{C}$ of $0.74 \mathrm{mS} / \mathrm{cm}$ and, therefore, was classified as a medium pozzolanic material $(0.4 \mathrm{mS} / \mathrm{cm}<\Delta \mathrm{C}<1.2 \mathrm{mS} / \mathrm{cm})$. The mean pozzolanicity of SBA was also observed for other bagasse ash assessed using the same methodology (ANDREÃO et al., 2019).

The mechanical performance index (PI) values are shown in Table 5 and confirmed the pozzolanic character of four ashes produced. In this case, all ashes presented PI values higher than $100 \%$, especially in RHA, CSA, and BLA, which corroborated the electrical conductivity test results. The compressive strength gain in mortars containing ashes could be attributed to characteristics such as high content of amorphous silica, reduced loss on ignition and high BET specific surface area. Moreover, the reduced ash particle size certainly contributed to the increase in mechanical strength by increasing packing density of mixes (CORDEIRO et al., 2008; CORDEIRO; KURTIS, 2017). SBA also achieved a satisfactory PI, however not as expressive as that observed for other ashes. SBA PI was in line with electrical conductivity results and with previous studies that indicated an intermediate pozzolanic activity for sugarcane bagasse ashes in mechanical tests (CORDEIRO et al., 2018). The better performance of SBA produced in this work in relation to different samples in the literature could be attributed to the reduced contamination of SBA by quartz and the citric acid leaching process, which provided the elimination of contaminating oxides, especially $\mathrm{K}_{2} \mathrm{O}$ (ANDREÃO et al., 2019).

Figure 8 shows the heat flow curves of reference mix and pastes containing RHA, SBA, CSA, and BLA. The curves were defined based on the binder mass and provided a clear view of the effect of each ash on hydration kinetics. The enlarged graphs of heat flow curves up to $8 \mathrm{~h}$ of hydration are also shown in Figure 8. Overall, all pastes exhibited the typical hydration behavior of a cementitious paste, with a first peak due to the initial contact between water and cement (which occurred outside the calorimeter and was not discussed in this work), induction, an acceleration period with maximum flow at the characteristic peak associated with $\mathrm{C}_{3} \mathrm{~S}$ hydration and a secondary peak corresponding to the $\mathrm{C}_{3} \mathrm{~A}$ reaction (BULLARD et al., 2011), followed by a progressive deceleration of reactions over time. 
Figure 6 - X-ray diffraction patterns of RHA, SBA, CSA, and BLA (peaks intensities in arbitrary unit)

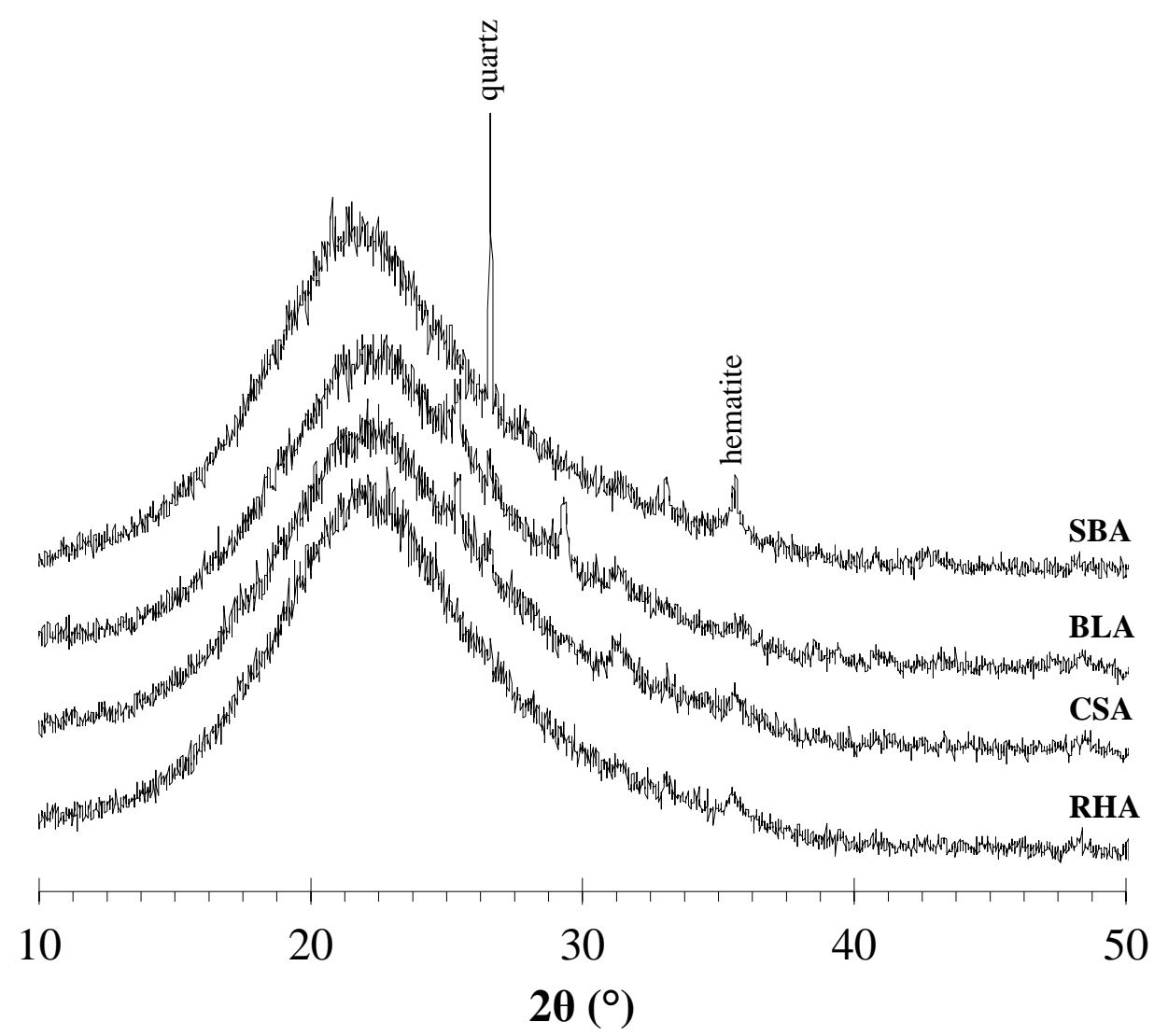

Figure 7 - Electrical conductivity curves of ashes during 20-min testing

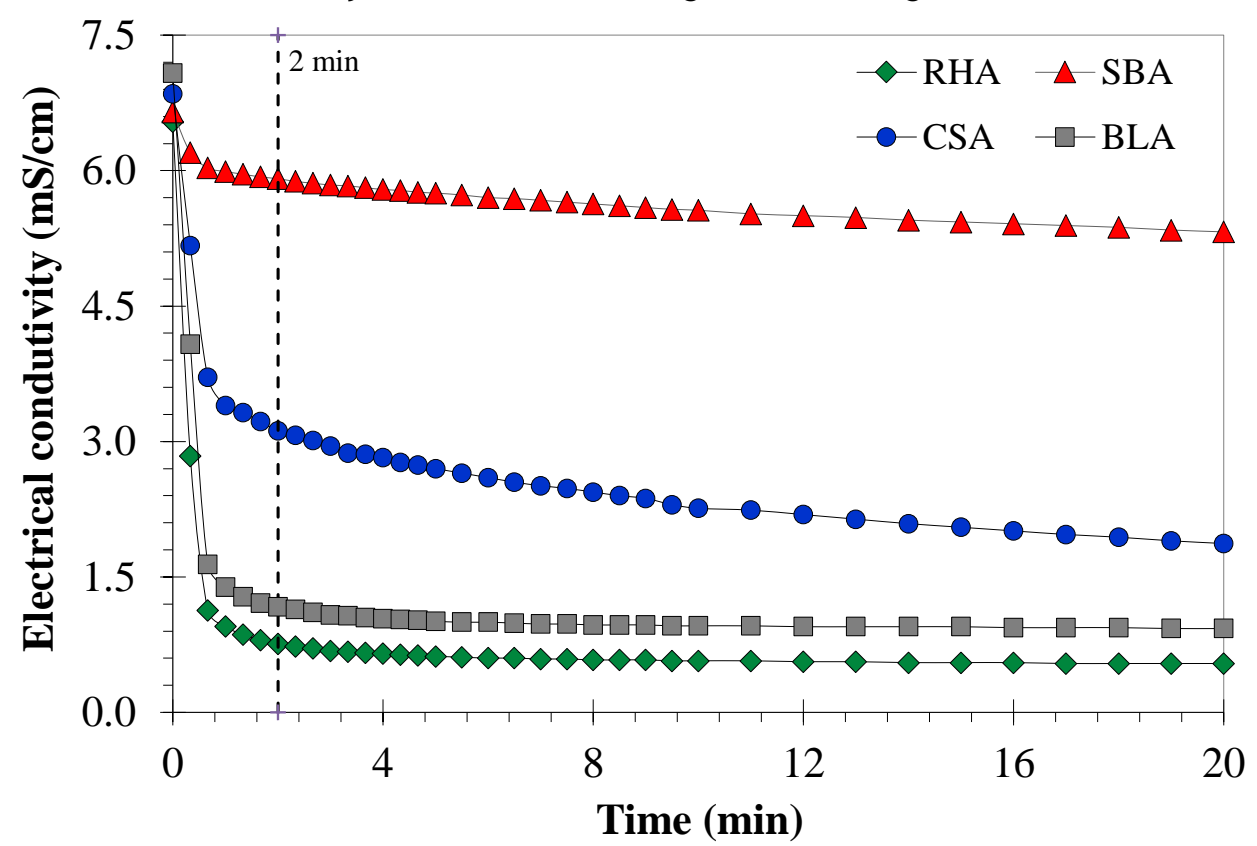


Figure 8 - Heat flow curves of reference and pastes containing $10 \%$ (a) and $20 \%$ (b) of RHA, SBA, CSA, and BLA

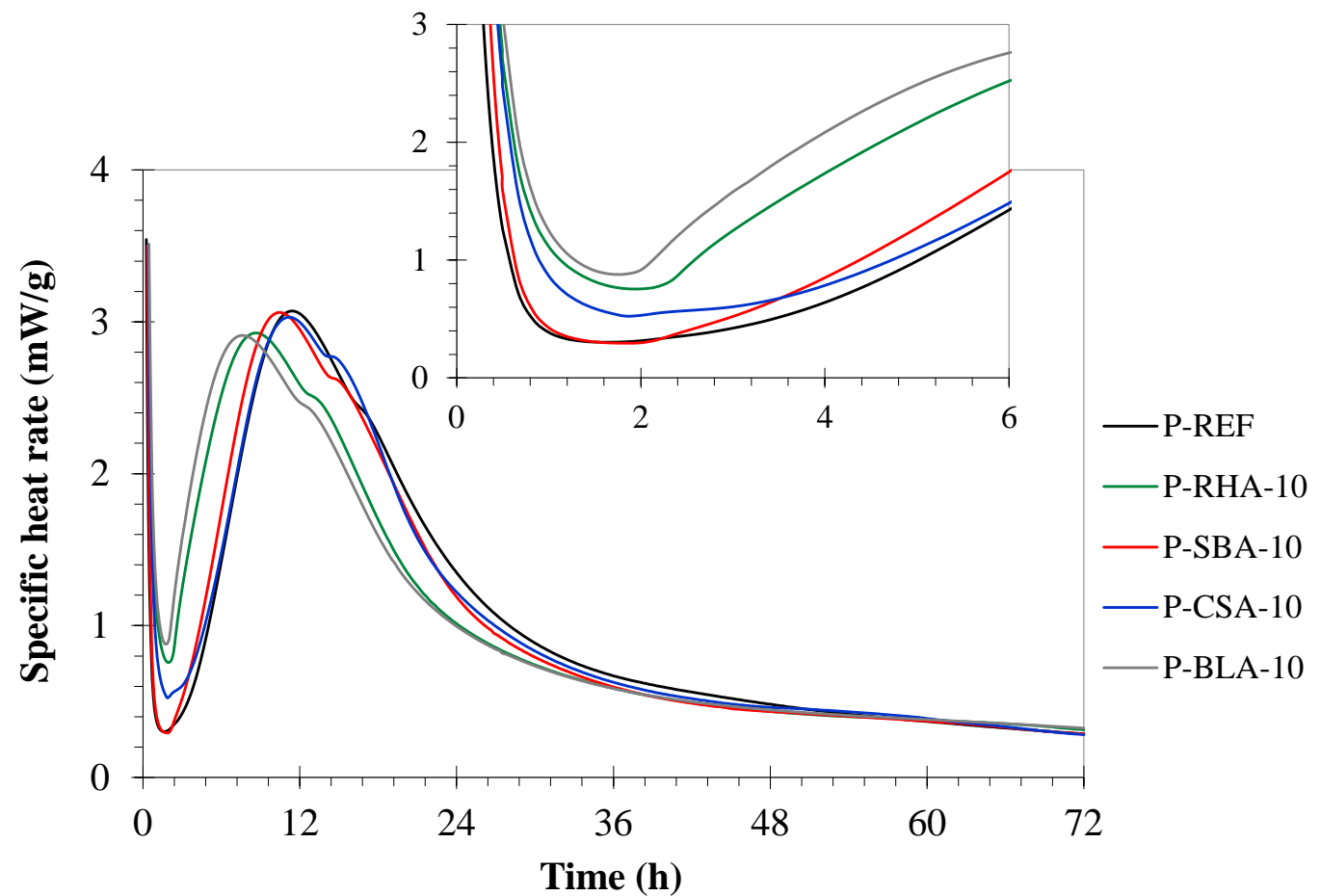

(a)

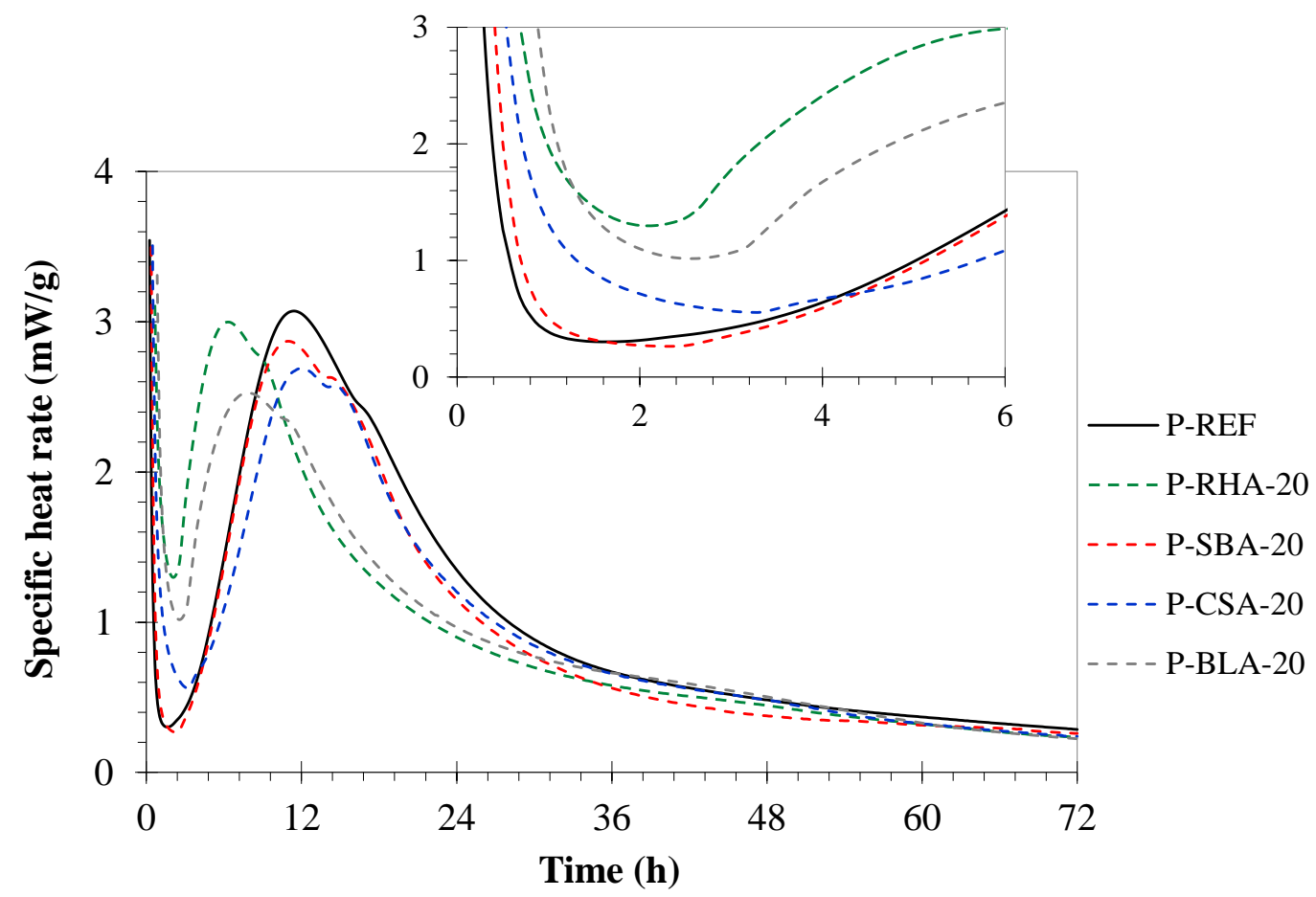

(b)

The results indicated that the addition of RHA promoted a slight reduction in the induction period for the two cement replacement contents evaluated, despite the opposite effect generated by the higher superplasticizer consumption (SAKAI et al., 2006), as indicated in Table 6. It should be noted that the amounts of superplasticizer used in pastes with RHA were significantly higher than that used in the reference (around 7 times higher). The reduction of induction period in pastes with RHA was due to dilution effects and, mainly, heterogeneous nucleation associated with this mineral addition (LAWRENCE; CYR;

198 Cordeiro, G. C.; Lemos, M. N.; Xavier, K. V.; Lima, C. P. F. de 
RINGOT, 2003; CORDEIRO; KURTIS, 2017). This behavior was also observed in BLA pastes, which proved the high reactivity of this ash. On the other hand, in spite of promoting an increase in heat flow in relation to the reference, pastes with SBA and CSA presented induction periods similar to that observed for the reference. This greater heat flow in the first hours of hydration may be associated with the presence of $\mathrm{K}_{2} \mathrm{O}$ in SBA and CSA mixes, which promoted a significant increase in the availability of alkalis in pastes with these ashes, as shown by the alkali equivalent $\left(\mathrm{Na}_{2} \mathrm{O}_{\text {eq }}\right)$ values of cementitious materials used in different pastes (Table 7). Similar results were previously observed by Andreão et al. (2019) and Cordeiro, Andreão and Tavares (2019) for pastes containing bagasse ashes. In addition, the extremely high BET specific surface area of CSA may have caused a reduction in the initial hydration rate due to the high-water demand by pozzolan (KORPA et al., 2008), even after correcting the consistency of pastes with the superplasticizer. It is interesting to note that there was an increase in the secondary peak (relative to the formation of monosulfate - AFm) in the ash pastes compared to the P-REF curve. This effect may be related to the heterogeneous nucleation of hydrates formed on the ultrafine pozzolanic particles (LAWRENCE; CYR; RINGOT, 2003) and also to a significant reduction in $\mathrm{SO}_{3}$ content (TAYLOR, 1997) in the binder of different blended pastes in relation to the reference, as shown in Table 7.

Figure 9 shows the accumulated released heat curves over $72 \mathrm{~h}$ of hydration. The accelerating effect of hydration reactions promoted by RHA and BLA was even more evident in the analysis of the accumulated heat of pastes, especially during the first day of hydration. On the other hand, the paste with $20 \%$ of SBA presented the lowest value of accumulated heat (Table 6). This showed the greater influence of the dilution effect compared to the other physical and chemical effects promoted by ash. The reduced values of the SBA specific surface area and pozzolanic activity compared to the other ashes also contributed to the reduction of accumulated heat for P-SBA-10 and P-SBA-20 in relation to the reference.

Table 6 - Parameters of isothermal calorimetry of different pastes

\begin{tabular}{c|c|c|c}
\hline Pasta & $\begin{array}{c}\text { Induction offset } \\
\text { time }(\mathbf{h}: \mathbf{m i n})\end{array}$ & $\begin{array}{c}\text { Maximum heat } \\
\text { flow }(\mathbf{m W} / \mathbf{g})\end{array}$ & $\begin{array}{c}\text { Released heat } \\
\text { at } \mathbf{7 2} \mathbf{~ h}(\mathbf{J} / \mathbf{g})\end{array}$ \\
\hline P-REF & $03: 24$ & 3.07 & 267.3 \\
P-RHA-10 & $02: 24$ & 2.93 & 265.9 \\
P- RHA-20 & $02: 30$ & 3.00 & 260.5 \\
P-SBA-10 & $03: 00$ & 3.06 & 264.2 \\
P-SBA-20 & $03: 30$ & 2.87 & 245.7 \\
P-CSA-10 & $03: 40$ & 3.03 & 268.8 \\
P-CSA-20 & $03: 50$ & 2.69 & 252.9 \\
P-BLA-10 & $01: 58$ & 2.91 & 267.9 \\
P-BLA-20 & $03: 12$ & 2.53 & 260.5 \\
\hline
\end{tabular}

Table $7-\mathrm{SO}_{3}$ content and alkali equivalent in terms of $\mathrm{Na}_{2} \mathrm{O}\left(\mathrm{Na}_{2} \mathrm{O}_{\text {eq }}\right)$ of paste binders

\begin{tabular}{c|c|c|c|c|c|c|c|c|c}
\hline \multirow{2}{*}{ Paste } & P- & P-RHA- & P-RHA- & P-SBA- P- SBA- & P-CSA- & P- CSA- & P-BLA- & P-BLA- \\
& REF & $\mathbf{1 0}$ & $\mathbf{2 0}$ & $\mathbf{1 0}$ & $\mathbf{2 0}$ & $\mathbf{1 0}$ & $\mathbf{2 0}$ & $\mathbf{1 0}$ & $\mathbf{2 0}$ \\
\hline $\mathrm{SO}_{3}$ & 3.60 & 3.37 & 3.15 & 3.47 & 3.34 & 3.51 & 3.42 & 3.50 & 3.39 \\
$\mathrm{Na}_{2} \mathrm{O}_{\mathrm{eq}}(\%) *$ & 0.78 & 0.71 & 0.64 & 0.85 & 0.93 & 0.84 & 0.90 & 0.71 & 0.64 \\
\hline
\end{tabular}

Note: $* \%$ of $\mathrm{Na}_{2} \mathrm{O}_{\text {eq }}$ in relation to mass binder. 
Figure 9 - Accumulated released heat curves of all pastes

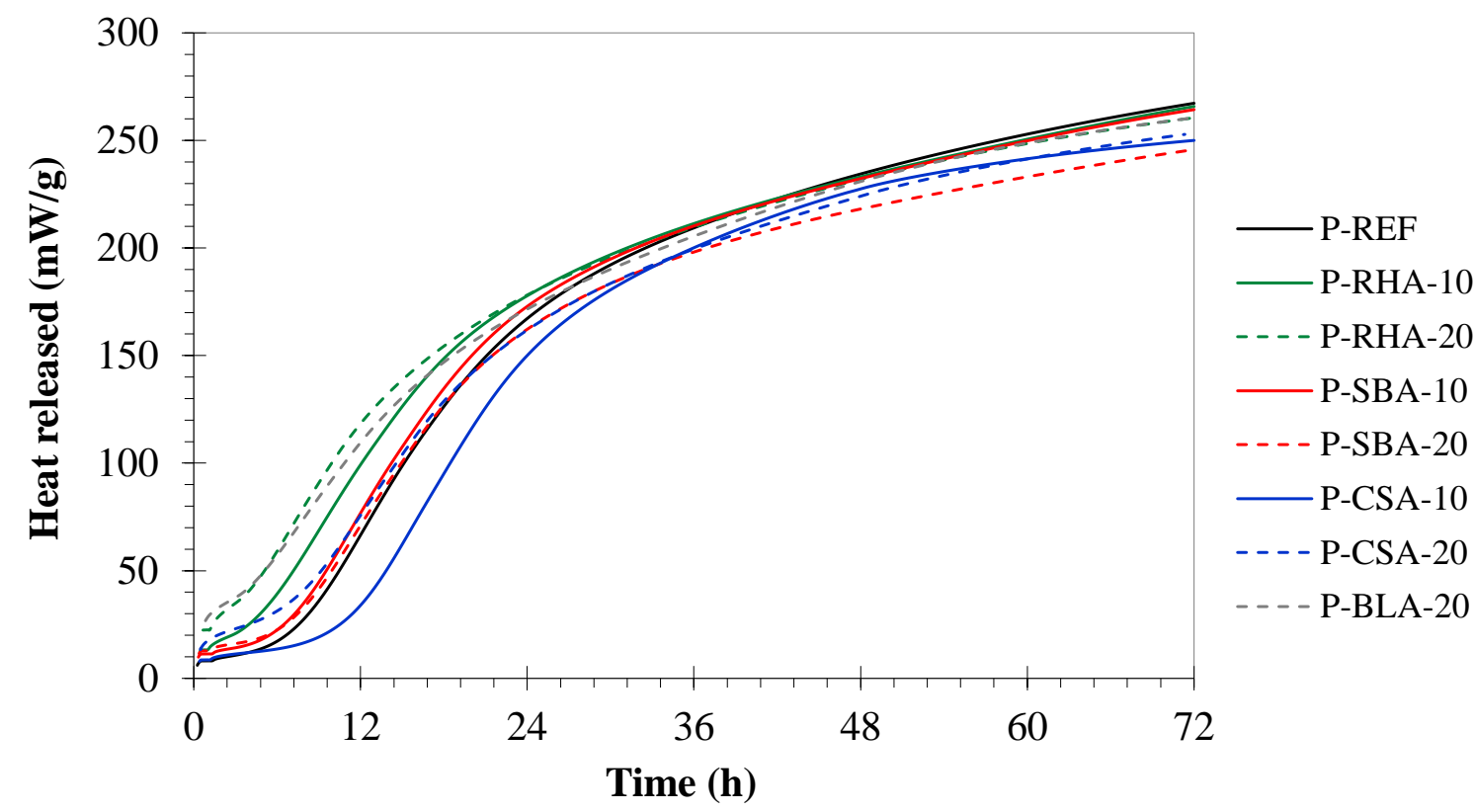

\section{Conclusions}

Based on this experimental research, the following conclusions could be drawn:

(a) the ashes produced by the confluence of different production methods presented typical properties of pozzolanic materials. From an efficient calcination process, the oxide composition of ashes showed high levels of amorphous silica $\left(\mathrm{SiO}_{2}\right)$ and reduced values of loss on ignition;

(b) the predominant presence of amorphous silica and high BET specific surface area allowed the classification of RHA, CSA, and BLA as ashes of good pozzolanicity and SBA as a material of medium pozzolanic activity, according to the electrical conductivity testing. The reactivity of the four ultrafine ashes was confirmed in the performance index evaluation, where the minimum value obtained of $107 \%$ was significantly higher than the minimum established by standard (90\%); and

(c) the partial cement replacement by ashes (10 and $20 \%$ by mass) promoted small changes in hydration kinetics of pastes during the first 3 days. The samples with greater reactivity (RHA and BLA) promoted a significant acceleration of reactions, while SBA generated an increase in induction period for the $20 \%$ cement replacement level.

Thus, it can be concluded that acid leaching combined with two-stage burning, and high-energy grinding procedures were efficient for producing pozzolans from biomass wastes. Finally, it should be noted that the leaching procedure can be carried out with acid effluents within biomass-based plants (e.g. vinasse, produced in ethanol distilleries). This practice would prevent the generation of new waste and contribute to the production of biomass ash with a more controlled chemical composition. Future research should be carried out with leaching using other types and different concentrations of acids, in addition to biomass samples of biomass from different sources.

\section{References}

ADESANYA, D. A.; RAHEEM, A. A. Development of corn cob ash blended cement. Construction and Building Materials, v. 23, p. 347-352, 2009.

AGÊNCIA FAPESP. Especialistas discutem papel da indústria do cimento nas emissões de $\mathrm{CO}_{2} .2016$. Available: http://agencia.fapesp.br/especialistas-discutem-papel-da-industria-do-cimento-nas-emissoes-deco2/23449/. Access em: 16 jun. 2019.

ANDREÃO, P. V. et al. Sustainable use of sugarcane bagasse ash in cement-based materials. Green Materials, v. 7, p. 61-70, 2019. 
ASSOCIAÇÃO BRASILEIRA DE NORMAS TÉCNICAS. NBR 12653: materiais pozolânicos: requisitos. Rio de Janeiro, 2015.

ASSOCIAÇÃO BRASILEIRA DE NORMAS TÉCNICAS. NBR 16697: cimento Portland: requisitos. Rio de Janeiro, 2018.

ASSOCIAÇÃO BRASILEIRA DE NORMAS TÉCNICAS. NBR 5752: materiais pozolânicos: determinação do índice de desempenho com cimento Portland aos 28 dias. Rio de Janeiro, 2014.

ASSOCIAÇÃO BRASILEIRA DE NORMAS TÉCNICAS. NBR 9831: cimento Portland destinado à cimentação de poços petrolíferos: requerimentos e métodos de ensaios. Rio de Janeiro, 2006.

ASSOCIAÇÃO BRASILEIRA DE NORMAS TÉCNICAS. NBR NM 18: cimento Portland: análise química: determinação de perda ao fogo. Rio de Janeiro, 2012.

BULlaRD, J. W. et al. Mechanism of cement hydration. Cement and Concrete Research, v. 41, p. 12081223, 2011.

CORDEIRO, G. C. et al. Influence of particle size and specific surface area on the pozzolanic activity of residual rice husk ash. Cement and Concrete Composites, v. 33, p. 529-534, 2011.

CORDEIRO, G. C. et al. Long-term compressive behavior of concretes with sugarcane bagasse ash as a supplementary cementitious material. Journal of Testing and Evaluation, v. 46, p. 564-573, 2018.

CORDEIRO, G. C. et al. Pozzolanic activity and filler effect of sugar cane bagasse ash in Portland cement and lime mortars. Cement and Concrete Composites, v. 30, p. 410-418, 2008.

CORDEIRO, G. C.; ANDREÃO, P. V.; TAVARES, L. M. Pozzolanic properties of ultrafine sugar cane bagasse ash produced by controlled burning. Heliyon, v. 5, p. e02566, 2019.

CORDEIRO, G. C.; BARROSO, T. R.; TOLEDO FILHO, R. D. Enhancement the properties of sugar cane bagasse ash with high carbon content by a controlled re-calcination process. KSCE Journal of Civil

Engineering, v. 22, p. 1250-1257, 2018.

CORDEIRO, G. C.; KURTIS, K. E. Effect of mechanical processing on sugar cane bagasse ash pozzolanicity. Cement and Concrete Research, v. 97, p. 41-49, 2017.

CORDEIRO, G. C.; SALES, C. P. Influence of calcining temperature on the pozzolanic characteristics of elephant grass ash. Cement and Concrete Composites, v. 73, p. 98-104, 2016.

CORDEIRO, G. C.; TAVARES, L. M.; TOLEDO FILHO, R. D. Improved pozzolanic activity of sugar cane bagasse ash by selective grinding and classification. Cement and Concrete Research, v. 89, p. 269-275, 2016.

CORDEIRO, G. C.; TOLEDO FILHO, R. D.; FAIRBAIN, E. M. R. Use of ultra-fine sugar cane bagasse ash as mineral admixture for concrete. ACI Materials Journal, v. 105, p. 487-493, 2008.

CORDEIRO, G. C.; VIEIRA, A. P.; LOPES, E. S. Study on the pozzolanic activity of sugar cane straw ash produced using different pretreatments. Química Nova, v. 40, p. 264-269, 2017.

DELLA, V. P.; KÜHN, I.; HOTZA, D. Rice husk ash as an alternate source for active silica production. Materials Letters, v 57, p. 818-821, 2002.

FENG, Q. et al. Study on the pozzolanic properties of rice husk ash by hydrochloric acid pretreatment. Cement and Concrete Research, v. 34, p. 521-526, 2004.

GANESAN, K.; RAJAGOPAL, K.; THANGAVEL, K. Evaluation of bagasse ash as supplementary cementitious material. Cement and Concrete Composites, v. 29, p. 515-524, 2007.

GARTNER, E. M. Industrially interesting approaches to 'low- $\mathrm{CO}_{2}$ ' cements. Cement and Concrete Research, v. 34, p. 1489-1498, 2004.

HOPPE FILHO, J. et al. Potencial de mitigação do ataque por sulfatos provocado por adições minerais. In: CONGRESSO BRASILEIRO DE PATOLOGIA DAS CONSTRUÇÕES, 1., Foz do Iguaçu, 2014. Anais [...] Foz do Iguaçu: ALCONPAT, 2014.

INSTITUTO BRASILEIRO DE GEOGRAFIA E ESTATÍSTICA. Levantamento sistemático da produção agrícola - LSPA. 2020. Disponível em: https://www.ibge.gov.br. Acesso em: 9 abr. 2020. 
JORGENSEN, J. D. Compression mechanisms in $\alpha$-quartz structures - $\mathrm{SiO}_{2}$ and $\mathrm{GeO}_{2}$. Journal of Applied Physics, v. 49, p. 5473-5478, 1978.

JUDZIEWICZ, E. J. et al. American bamboos. Washington, D.C.: Smithsonian Institution Press, 1999.

KORPA, A.; KOWALD, T.; TRETTING, R. Hydration behavior, structure and morphology of hydration phases in advanced cement-based systems containing micro and nanoscale pozzolanic additives. Cement and Concrete Research, v. 38, p. 955-962, 2008.

KRISHNARAO, R. V.; SUBRAHMANYAM, J.; JAGADISH KUMAR, T. Studies on the formation of black particles in rice husk silica ash. Journal of the European Ceramic Society, v. 21, p. 99-104, 2001.

LAWRENCE, P.; CYR, M.; RINGOT, E. Mineral admixtures in mortars: effect of inert materials on shortterm hydration. Cement and Concrete Research, v. 33, p. 1939-197, 2003.

LIU, H.; KUO, C. Quantitative multiphase determination using the Rietveld method with high accuracy. Materials Letters, v. 26, p. 171-175, 1996.

LUXÁN, M. P.; MADRUGA, F.; SAAVEDRA, J. Rapid evaluation of pozzolanic activity of natural products by conductivity measurement. Cement and Concrete Research, v. 19, p. 63-68, 1989.

MALHOTRA, V. M.; MEHTA, P. K. Pozzolanic and cementitious materials. Amsterdam: Gordon and Breach Publishers, 1996.

MARTIRENA HERNÁNDEZ, J. F. M. et al. Use of wastes of the sugar industry as pozzolana in limepozzolana binders: study of the reaction. Cement and Concrete Research, v. 28, p. 1525-1536, 1998.

MEHTA, P. K.; MONTEIRO, P. J. M. Concrete: microstructure, properties, and materials. $4^{\text {th }}$. ed. New York: McGraw-Hill Education, 2014.

REAL, C.; ALCALÁ, M. D.; CRIADO, J. M. Preparation of silica from rice husks. Journal of the American Ceramic Society, v. 79, p. 2012-2016, 1996.

RIBAS, L. et al. Measuring the strength of irregularly-shaped fine particles in a microcompression tester. Minerals Engineering, v. 65, p. 149-155, 2014.

RICHARDSON, I. G.; GROVES, G. W. The incorporation of minor and trace elements into calcium silicate hydrate (C-S-H) gel in hardened cement pastes. Cement and Concrete Research, v. 3, p. 131-138, 1993.

ROSSIGNOLO, J. A. et al. Influence of microwave oven calcination on the pozzolanicity of sugar cane bagasse ashes (SCBA) from the cogeneration industry. Construction and Building Materials, v. 187, p. 892-902, 2018.

SABIR, B. B.; WILD, S.; BAI, J. Metakaolin and calcined clays as pozzolans for concrete: a review. Cement and Concrete Composites, v. 23, p. 441-454, 2001.

SAKAI, E. et al. Influence of superplasticizers on the hydration of cement and the pore structure of hardened cement. Cement and Concrete Research, v. 36, p. 2049-2053, 2006.

SOUZA, L. M. S. et al. Influence of initial $\mathrm{CaO} / \mathrm{SiO}_{2}$ ratio on the hydration of rice husk ash- $\mathrm{Ca}(\mathrm{OH})_{2}$ and sugar cane bagasse ash-Ca(OH) 2 pastes. Química Nova, v. 37, p. 1600-1605, 2014.

SUGITA, S. Method of producing active rice husk ash. United States Patent US 5329867 A, 1994.

TASHIMA, M. M. et al. High reactive rice husk ash (RHA): Production method and pozzolanic reactivity. Ambiente Construído, Porto Alegre, v. 12, n. 2, p. 151-163, 2012.

TAYLOR, H. F. M. Cement chemistry. $2^{\text {nd }}$. ed London: Thomas Telford Publishing, 1997.

THOMMES, M. et al. Physisorption of gases, with special reference to the evaluation of surface area and pore size distribution (IUPAC Technical Report). Pure and Applied Chemistry, v. 87, p. 1051-1069, 2015.

VAYGHAN, A. G.; KHALOO, A. R.; RAJABIPOUR, F. The effects of a hydrochloric acid pre-treatment on the physicochemical properties and pozzolanic performance of rice husk ash. Cement and Concrete Composites, v. 39, p. 131-140, 2013.

VIEIRA, A. P. et al. Effect of particle size, porous structure and content of rice husk ash on the hydration process and compressive strength evolution of concrete. Construction and Building Materials, v. 236, p. $117553,2020$. 
VILLAR-COCIÑA, E. et al. Pozzolanic behavior of bamboo leaf ash: characterization and determination of the kinetic parameters. Cement and Concrete Composites, v. 33, p. 68-73, 2011.

ZHANG, M. H.; MALHOTRA, M. High-performance concrete incorporating rice husk ash as a supplementary cementing material. ACI Materials Journal, v. 93, p. 629-636, 1996.

\section{Acknowledgments}

This study was partially funded by the Coordenação de Aperfeiçoamento de Pessoal de Nível Superior Brasil (CAPES) - Finance Code 001. The authors would like to thank the Brazilian Conselho Nacional de Desenvolvimento Científico e Tecnológico $(\mathrm{CNPq})$ and Fundação Carlos Chagas Filho de Amparo à Pesquisa do Estado do Rio de Janeiro (FAPERJ) agencies.

Guilherme Chagas Cordeiro

Laboratório de Engenharia Civil | Universidade Estadual do Norte Fluminense Darcy Ribeiro | Av. Alberto Lamego, 2000 | Campos dos Goytacazes - RJ - Brasil | CEP 28013-602 | Tel.: (22) 2737-7373 | E-mail: gcc@uenf.br

\section{Mônica Nunes Lemos}

Laboratório de Engenharia Civil | Universidade Estadual do Norte Fluminense Darcy Ribeiro | E-mail: monica.nlemos@gmail.com

Kristian Vinco Xavier

Laboratório de Engenharia Civil | Universidade Estadual do Norte Fluminense Darcy Ribeiro | E-mail: kristianvinco@gmail.com

\section{Charles Prado Ferreira de Lima}

Laboratório de Engenharia Civil | Universidade Estadual do Norte Fluminense Darcy Ribeiro | E-mail: pflcharles@gmail.com

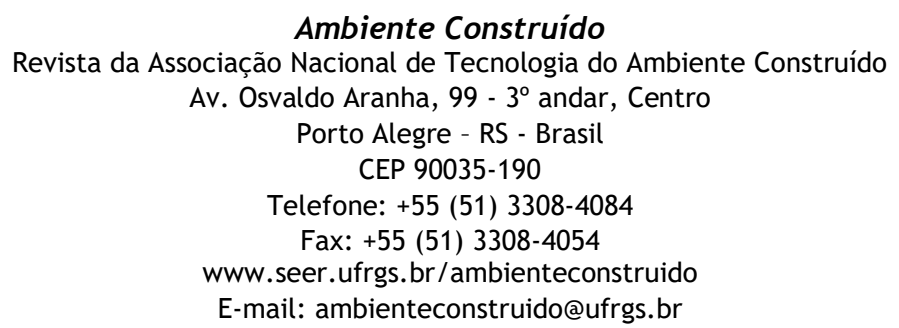

